\title{
Long-term medical treatment in congenital hyperinsulinism: a descriptive analysis in a large cohort of patients from different clinical centers
}

\author{
Alena Welters ${ }^{1 *}$, Christian Lerch², ${ }^{2,}$ Sebastian Kummer $^{1}$, Jan Marquard ${ }^{1}$, Burak Salgin ${ }^{1,4,5}$, Ertan Mayatepek \\ and Thomas Meissner ${ }^{1}$
}

\begin{abstract}
Background: Up to now, only limited data on long-term medical treatment in congenital hyperinsulinism (CHI) is available. Moreover, most of the drugs used in $\mathrm{CH}$ are therefore not approved. We aimed to assemble more objective information on medical treatment in $\mathrm{CH}$ with regard to type and duration, dosage as well as side effects.

Methods: We searched MEDLINE (from 1947) and EMBASE (from 1988) using the OVID interface for relevant data to evaluate medical treatment in a large cohort of patients with $\mathrm{CH}$ from different clinical centers. Randomized, controlled trials were not available. We evaluated case reports and case series. No language restrictions were made.

Results: A total number of 619 patients were medically treated and information regarding conservative treatment was available. Drugs used were diazoxide (in $84 \%$ of patients), somatostatin analogues (16\%), calcium channel antagonists (4 \%) and glucagon (1 \%). Mean dose of diazoxide was $12.5( \pm 4.3) \mathrm{mg} / \mathrm{kg} \cdot \mathrm{d}$ (range $2-60 \mathrm{mg} / \mathrm{kg} \cdot \mathrm{d})$, mean duration of diazoxide treatment until remission was 57 months. Side effects of diazoxide were usually not severe. The causal relation between diazoxide and severe side effects, e.g. heart failure (3.7 \%) remains doubtful. Mean dose of octreotide was 14.9 $( \pm 7.5) \mu \mathrm{g} / \mathrm{kg} \cdot \mathrm{d}$ (range $2.3-50 \mu \mathrm{g} / \mathrm{kg} \cdot \mathrm{d}$ ), of lanreotide $67.3( \pm 39.8) \mathrm{mg} \cdot$ month (range 10-120 mg $\cdot$ month). Mean duration of treatment with somatostatin analogues until remission was 49 months. Frequent side effects included tachyphylaxis and mild gastrointestinal symptoms. The risk of persistent growth deceleration was low $(<5 \%)$.
\end{abstract}

Conclusions: Severe side effects are rare and a causal relation remains disputable. We conclude that long-term conservative treatment of $\mathrm{CHI}$ is feasible.

Keywords: Congenital hyperinsulinism, Persistent hyperinsulinemic hypoglycemia of infancy, Diazoxide, Octreotide, Lanreotide, Nifedipine, Glucagon

\section{Background}

Congenital hyperinsulinism (CHI) is a heterogeneous disorder leading to increased, often unregulated secretion of insulin from pancreatic beta cells. Clinical manifestation ranges from life-threatening hypoglycemia in neonates to mildly symptomatic hypoglycemia in early childhood, adolescence or adulthood that might sometimes be

\footnotetext{
* Correspondence: Alena.Welters@med.uni-duesseldorf.de

'Department of General Pediatrics, Neonatology and Pediatric Cardiology, University Children's Hospital Duesseldorff, Moorenstrasse 5, Duesseldorf D-40225, Germany

Full list of author information is available at the end of the article
}

difficult to identify [1]. Up to now, mutations in nine different genes have been identified. However, in almost $50 \%$ of CHI-cases, the genetic mechanism is still unknown, suggesting further disease-associated genes $[2,3]$. $\mathrm{CHI}$ can be distinguished into a diffuse and focal type. Focal $\mathrm{CHI}$ is defined as a focal adenomatous hyperplasia of beta cells within the pancreatic tissue, which can be identified by $18 \mathrm{~F}-\mathrm{PET} / \mathrm{CT}$ and completely cured by surgical removal of the focal lesion $[4,5]$.

In contrast, in diffuse $\mathrm{CHI}$ hyperplastic insulin-secreting beta cells are spread throughout the whole pancreas. Sufficient reduction of hyperinsulinemia usually requires near 
total pancreatectomy, which in turn implicates the risk of either persistent hypoglycemia or insulin-requiring diabetes $[6,7]$. Therefore, long-term medical treatment was established during the last decades for diffuse $\mathrm{CHI}$. If $\mathrm{CHI}$ is promptly diagnosed and adequately treated most of the children develop a normal range of cognitive, emotional and social skills. In these cases, clinical remission with termination of all drugs may occur after several years of intense conservative treatment $[8,9]$. Common conservative long-term treatment options include the potassium channel opener diazoxide (which is almost ineffective in patients with defects of the $\mathrm{K}_{\mathrm{ATP}}$-channel), somatostatin analogues (octreotide, lanreotide) or calcium-channel antagonists [6,9-11]. Although these drugs are frequently used in patients with $\mathrm{CHI}$, little is known about their dose, efficacy and safety. Evidence-based guidelines to manage recurrent hyperinsulinemic hypoglycemia do not exist and therefore treatment strategies remain controversial. Improved knowledge and optimization of conservative treatment is thus of major importance, especially in diffuse $\mathrm{CHI}$, in which surgical cure cannot easily be achieved [7]. At present, treatment decisions are mostly based on expert opinions obtained from single-center data.

This review aims to provide more objective information collected from reports of more than 600 patients from different clinical centers. Thereby, we provide an overview of long-term conservative treatment in $\mathrm{CHI}$ with regard to type and duration of treatment, dose and frequency of severe as well as rare side effects that are often difficult to assess in small patient cohorts and single-center experiences.

\section{Methods}

We searched MEDLINE (from 1947) and EMBASE (from 1988) using the OVID interface for relevant data. Search terms were combined for the disease, specific drugs and generic treatment options. Additional articles were found by cross-reading reference lists of retrieved articles. Efforts were made to translate non-english articles, which allowed us to include all relevant German, Spanish, French, Portuguese, Turkish, Danish, Polish, Chinese and Japanese articles. The latest article included for evaluation was published in June 2013.

\section{Results}

In total 113 articles, mainly case reports and case series were evaluated with specific regard to long-term conservative treatment. The reviewed literature included a total of 1261 patients with CHI, of which 718 patients received long-term conservative treatment during their course of disease. Long-term treatment was defined as minimum duration of 6 months. Reports were also included if treatment lasted for at least two months at the time of publication but was described as being ongoing.
For 50/718 patients a specific treatment regimen was not necessary or not mentioned, another 49 patients were solely treated by frequent feedings and/or specific diets. Finally, 619 patients were medically treated and information regarding conservative treatment was available. These patients are described separately. The medication most commonly used to control hypoglycemia was diazoxide $(84 \%)$ followed by somatostatin analogues (16\%), calcium channel antagonists (4\%) and glucagon (1\%) (Table 1). For evaluation of side effects, we included all patients that did not meet our definition of long-term treatment. In order to obtain as much information as possible on very rare side effects, we furthermore discuss single patients that experienced such side effects but were treated with one of the studied medications because of a disease other than CHI (e.g. octreotide in the treatment of congenital chylothorax). These latter patients are clearly defined within the text and were not included in the analysis resulting in table 2 (Table 2).

\section{Dietary treatment}

In 49 patients a "sufficient control" of hypoglycemia was achieved with nutritional treatment. Importantly, the definition of "sufficient control" might vary greatly among the different hyperinsulinism centers further stressing the necessity of establishing a standardized fasting tolerance test to better compare the response to dietary or medical treatment in between the different clinical centers.

Almost half of these patients ( $49 \%$ ) were fed frequently with glucose-enriched meals. Another eight patients $(16 \%)$ additionally required raw cornstarch and also glucocorticoids for a sufficient control of hypoglycemia [12]. Seventeen patients $(35 \%)$ were treated with a leucinerestricted diet, of which all except two patients suffered from the Hyperinsulinism-Hyperammonemia Syndrome (HI/HA) caused by a mutation of the GLUD1 gene. The other two patients treated with a leucine-restricted diet were subsequently diagnosed as carrying a dominantly inherited SUR1 mutation. Both of them developed mental retardation due to recurrent seizures [13].

\section{Discussion}

The purpose of this study was to assemble information on medical treatment of $\mathrm{CHI}$ with specific regard to type and duration of treatment, dose, as well as side effects. Since we collected as much information as available, including case reports in various languages from different clinical centers worldwide, the strength of the evidence has to be critically assessed. Our results are biased by the fact that publication practices tend to favor positive treatment responses and that very rare or severe side effects are more likely to be published. However, we 
Table 1 Characteristics of long-term conservative treatment in $\mathrm{CHI}$ : detailed description of different treatment regimen with focus on dose, combination of different drugs and duration of treatment. Patients receiving a combined therapy are listed twice

\begin{tabular}{|c|c|c|c|c|}
\hline Drug & Long-term treated & Combined therapy & Dose & Course of treatment \\
\hline$\overline{D Z X}$ & $\begin{array}{l}\mathrm{n}_{\text {total }} 521 \\
\mathrm{n} \text { previous surgery } 16(3 \%) \\
\text { monotherapy } \\
\mathrm{n}=380(73 \%) \\
\text { combined therapy } \\
\mathrm{n}=141(27 \%)\end{array}$ & $\begin{array}{l}+\operatorname{diet}^{a} n=113(79 \%) \\
+ \text { STA } n=9(6 \%) \\
+ \text { CCA } n=2(1 \%) \\
>2 \text { combinations } \\
+ \text { STA + } \operatorname{diet}^{\mathrm{a}} n=15(11 \%) \\
+ \text { CCA + } \operatorname{diet}^{\mathrm{a}} \mathrm{n}=2(1 \%)\end{array}$ & $\begin{array}{l}\mathrm{n} \text { dose given } 278(53 \%) \\
\text { mean: } 12.5( \pm 4.3) \mathrm{mg} / \mathrm{kg} \cdot \mathrm{d} \\
\text { range: } 2-60 \mathrm{mg} / \mathrm{kg} \cdot \mathrm{d} \\
2-3 \text { single doses p.o. } \cdot \mathrm{d}\end{array}$ & $\begin{array}{l}\mathrm{n} \text { treatment ongoing } 138(26 \%) \\
\text { duration given for } \mathrm{n}=113 / 138(82 \%) \\
\text { mean duration: } 62 \text { months } \\
\mathrm{n} \text { off medication } 69(13 \%) \\
\text { duration given for } \mathrm{n}=56 / 69(81 \%) \\
\text { mean duration: } 57 \text { months } \\
\mathrm{n} \text { switched to other therapy } 4(1 \%) \\
\text { partial pancreatectomy: } 3 / 4(75 \%) \\
\text { STA: } 1 / 4 \text { ( } 25 \%) \\
\mathrm{n} \text { not mentioned; no follow-up } 309(59 \%) \\
\mathrm{n} \text { dead } 1(0.2 \%)\end{array}$ \\
\hline STA & $\begin{array}{l}\mathrm{n} \text { total } 100 \\
\text { OCT } \mathrm{n}=79(79 \%) \\
\text { LRT } \mathrm{n}=21(21 \%) \\
\mathrm{n} \text { previous surgery } 17(17 \%) \\
\text { monotherapy } \\
\mathrm{n}=54(54 \%) \\
\text { combined therapy } \\
\mathrm{n}=46(46 \%)\end{array}$ & $\begin{array}{l}+\operatorname{diet}^{a} n=16(35 \%) \\
+ \text { DZX } n=9(20 \%) \\
+ \text { CCA } n=4(9 \%) \\
+ \text { GLC } n=2(4 \%) \\
\text { >2 combinations } \\
+ \text { DZX + } \operatorname{diet}^{a} n=15(11 \%)\end{array}$ & $\begin{array}{l}\text { OCT } \\
\mathrm{n} \text { dose given } 61(77 \%) \\
\text { mean: } 14.9( \pm 7.5) \mu \mathrm{g} / \mathrm{kg} \cdot \mathrm{d} \\
\text { range: } 2.3-50 \mu \mathrm{g} / \mathrm{kg} \cdot \mathrm{d} \\
\text { continuously s.c. } \mathrm{n}=28(46 \%) \\
\text { 3-6 injections s.c. } \cdot \mathrm{d} n=17(28 \%) \\
\text { not specified } \mathrm{n}=16(26 \%) \\
\text { LRT } \\
\mathrm{n} \text { dose given } 11(52 \%) \\
\text { mean: } 67.3( \pm 39.8) \mathrm{mg} \cdot \text { month } \\
\text { range: } 10-120 \mathrm{mg} \cdot \text { month } \\
\text { s.c. } \mathrm{n}=8(38 \%) \\
\text { i.m. } \mathrm{n}=13(62 \%)\end{array}$ & $\begin{array}{l}\mathrm{n} \text { treatment ongoing } 39(39 \%) \\
\text { duration given for } \mathrm{n}=39 / 39(100 \%) \\
\text { mean duration: } 35 \text { months } \\
\mathrm{n} \text { off medication } 22(22 \%) \\
\text { duration given for } \mathrm{n}=6 / 22(27 \%) \\
\text { mean duration: } 49 \text { months } \\
\mathrm{n} \text { switched to other therapy } 10(10 \%) \\
\text { partial pancreatectomy: } 3 / 10(30 \%) \\
\text { DZX: } 3 / 10(30 \%) \\
\text { gastrostomy feeding: } 2 / 10(20 \%) \\
\text { DZX + CCA: } 1 / 10(10 \%) \\
\text { megestrol acetate: } 1 / 10(10 \%) \\
\mathrm{n} \text { not mentioned; no follow-up } 29(29 \%)\end{array}$ \\
\hline CCA & $\begin{array}{l}n_{\text {total }} 25 \\
\text { NIF } n=19(76 \%) \\
\text { VPM }{ }^{\circ} n=2(8 \%) \\
\text { AML } n=1(4 \%) \\
\text { not specified } n=3(12 \%) \\
n \text { previous surgery } 10(40 \%) \\
\text { monotherapy } \\
n=15(60 \%) \\
\text { combined therapy } \\
n=10(40 \%)\end{array}$ & $\begin{array}{l}+\operatorname{diet}^{a} n=2(20 \%) \\
+ \text { DZX } n=2(20 \%) \\
+ \text { STA } n=4(40 \%) \\
>2 \text { combinations } \\
+ \text { DZX + } \operatorname{diet}^{a} n=2(20 \%)\end{array}$ & $\begin{array}{l}\mathrm{NIF} \\
\mathrm{n} \text { dose given } 18(95 \%) \\
\text { mean: } 0.72( \pm 0.36) \mathrm{mg} / \mathrm{kg} \cdot \mathrm{d} \\
\text { range: } 0.1-2 \mathrm{mg} / \mathrm{kg} \cdot \mathrm{d} \\
\text { VPM } \\
\mathrm{n} \text { dose given } 2(100 \%) \\
\text { dose: } 240 \mathrm{mg} \cdot \mathrm{d} \\
\mathrm{AML} \\
\mathrm{n}_{\text {dose given }} 1(100 \%) \\
\text { dose: } 0.1 \mathrm{mg} / \mathrm{kg} \cdot \mathrm{d} \\
2-4 \text { single doses p.o. } \cdot \mathrm{d}\end{array}$ & $\begin{array}{l}\mathrm{n} \text { treatment ongoing } 16(64 \%) \\
\text { duration given for } \mathrm{n}=16 / 16(100 \%) \\
\text { mean duration: } 25 \text { months } \\
\mathrm{n} \text { not mentioned; no follow-up } 9(36 \%)\end{array}$ \\
\hline GLC & $\begin{array}{l}n_{\text {total }} 7 \\
n_{\text {previous surgery }} 6(86 \%) \\
\text { monotherapy } \\
n=2(29 \%) \\
\text { combined therapy } \\
n=5(71 \%)\end{array}$ & $\begin{array}{l}+\operatorname{diet}^{\mathrm{a}} n=3(60 \%) \\
+ \text { STA } n=2(40 \%)\end{array}$ & $\begin{array}{l}\mathrm{n}_{\text {dose given }} 7(100 \%) \\
\text { given as } \mathrm{mg} / \mathrm{kg} \cdot \mathrm{d} \text { : } \mathrm{n}=5(71 \%) \\
\text { mean: } 0.186( \pm 0.14) \mathrm{mg} / \mathrm{kg} \cdot \mathrm{d} \\
\text { range: } 0.03-0.2 \mathrm{mg} / \mathrm{kg} \cdot \mathrm{d}_{\text {continuously s.c. }} \\
\text { given as } \mathrm{mg} \cdot \mathrm{d} \text { : } \mathrm{n}=2(29 \%) \\
\text { mean: } 3.2 \mathrm{mg} \cdot \mathrm{d} \\
\text { s.c. or i.m. }\end{array}$ & $\begin{array}{l}\mathrm{n} \text { treatment ongoing } 1(14 \%) \\
\text { duration given for } \mathrm{n}=1 / 1(100 \%) \\
\text { mean duration: } 12 \text { months } \\
\mathrm{n} \text { off medication } 3(43 \%) \\
\text { duration given for } \mathrm{n}=3 / 3(100 \%) \\
\text { mean duration: } 43 \text { months } \\
\mathrm{n}_{\text {switched to other therapy } 2(29 \%)} \\
\text { re-pancreatectomy: } 1 / 2(50 \%) \\
\text { diet : } 1 / 2(50 \%) \\
\mathrm{n}_{\text {dead }} 1(14 \%)\end{array}$ \\
\hline
\end{tabular}

${ }^{2}$ Diet frequent feeding, glucose enriched meals (dextrin, tapioca starch, ricepap), gastrostomy feeding, ${ }^{\circ} V P M$ two patients with adult-onset nesidioblastosis DZX diazoxide, STA somatostatin analogue, CCA calcium channel antagonists, GLC glucagon, OCT octreotide, LRT lanreotide (long-acting release octreotide), NIF nifedipine, VPM verapamil, $A M L$ amlodipine

believe that with a more rigorous approach with regard to the quality of data, a lot of important information would have been lost. The lack of objective information on long-term medical treatment in $\mathrm{CHI}$, in particular with respect to the heterogeneity of the condition itself is a general dilemma for the treatment of patients with $\mathrm{CHI}$ and appropriate counseling of their parents. We are therefore convinced that the careful recapitulation of what has been reported for a large cohort of patients might help to improve the knowledge and decisions on long-term treatment of $\mathrm{CHI}$ even with respect to the weakness that published data are biased and the lack of a more critical approach to the evaluation of the reports.

\section{Diazoxide}

Diazoxide is a $\mathrm{K}_{\mathrm{ATP}}$-channel opener and the only drug approved by the Food and Drug Administration (FDA) for long-term treatment of hyperinsulinemic hypoglycemia. However, many patients are diazoxide resistant due to mutations in the two genes encoding the $\mathrm{K}_{\mathrm{ATP}}$-channel of the pancreatic beta cell $(A B C C 8 / K C N J 11)$ [14] In total 521 patients were treated long-term with diazoxide, either 
Table 2 Side effects in medically treated patients with CHI: overview of side effects that occurred while on therapy with one or more of the analyzed medication. Side effects were linked to the corresponding dose that was applied. Note double entries of patients that experienced more than one side effect

\begin{tabular}{|c|c|c|c|c|}
\hline Drug & $\mathrm{n}$ treated & Side effects & Frequency & Dose ( $n$ dose given) \\
\hline \multirow{10}{*}{ DZX } & & & & $\mathrm{mg} / \mathrm{kg} \cdot \mathrm{d}$ \\
\hline & DZX treated $n=644$ & hypertrichosis & $n=170(52 \%)$ & $11.6( \pm 2.9)$, range $5-30(n=132)$ \\
\hline & side effects mentioned $n=325(50 \%)$ & fluid retention/electrolyte imbalances/edema & $\mathrm{n}=99(30 \%)$ & $12.3( \pm 2.8)$, range $8.5-17.5(n=48)$ \\
\hline & & vomiting/poor appetite & $\mathrm{n}=40(12 \%)$ & $13.3( \pm 8.2)$, range $10-60(n=39)$ \\
\hline & & bone marrow suppression & $\mathrm{n}=11(3 \%)$ & $10.4( \pm 0.46)$, range $10-10.8(n=4)$ \\
\hline & & heart failure & $\mathrm{n}=12(3.7 \%)$ & $16( \pm 6.7)$, range $7.5-30(n=7)$ \\
\hline & & anaphylactic reaction & $n=3(0.9 \%)$ & $8.5(n=1)$ \\
\hline & & renal failure & $n=2(0.6 \%)$ & $60(n=1)$ \\
\hline & & sinustachycardia & $\mathrm{n}=1(0.3 \%)$ & up to $15(n=1)$ \\
\hline & & no (major) side effects (specifically mentioned) & $\mathrm{n}=39(12 \%)$ & $13.2( \pm 2.4)$, range $5-15(n=34)$ \\
\hline \multirow{13}{*}{ STA } & & & & $\mu \mathrm{g} / \mathrm{kg} \cdot \mathrm{d}$ or otherwise specified \\
\hline & STA treated $n=355$ & tachyphylaxis & $\mathrm{n}=20(18 \%)$ & $19.5( \pm 7.3)$, range $7.1-26.3(n=18)$ \\
\hline & side effects mentioned $n=111(31 \%)$ & Gl-symptoms* & $n=23(21 \%)$ & $17.5( \pm 9.5)$, range $6.6-27.4(n=20)$ \\
\hline & & (transient) impairment in growth velocity & $\mathrm{n}=15(14 \%)$ & $17.8( \pm 13.5)$, range $7.2-55(n=14)$ \\
\hline & & abnormal GH, IGF, IGF-BP (no growth impairment) & $n=4(3.6 \%)$ & $25.8( \pm 0.72)$, range $25-26.3(n=3)$ \\
\hline & & necrotizing enterocolitis & $\mathrm{n}=8(7 \%)$ & $21.5( \pm 4.7)$, range $15-27(n=6)$ \\
\hline & & induration nodules/hematoma at injection site & $n=5(4.5 \%)$ & $120 \mathrm{mg} \cdot$ month $(\mathrm{n}=2)$ \\
\hline & & decline in weight & $\mathrm{n}=3(2.7 \%)$ & $25(n=1)$ \\
\hline & & asymptomatic gallstones & $n=3(2.7 \%)$ & $33.9( \pm 24.8)$, range $6.6-55(n=3)$ \\
\hline & & cholestatic jaundice & $n=1(0.9 \%)$ & $40(n=1)$ \\
\hline & & elevated liver enzymes & $\mathrm{n}=3(2.7 \%)$ & $16.8( \pm 11.4)$, range $10-30(n=3)$ \\
\hline & & anaphylactic reaction & $\mathrm{n}=1(0.9 \%)$ & not specified \\
\hline & & normal growth velocity (specifically mentioned) & $n=52(47 \%)$ & $\begin{array}{l}19( \pm 8.7) \text {, range 8-55 }(n=32) 100( \pm 15.5) \mathrm{mg} \cdot \text { month, } \\
\text { range } 90-120(n=6)\end{array}$ \\
\hline \multirow{6}{*}{ GLC } & & & & $\mathrm{mg} / \mathrm{kg} \cdot \mathrm{d}$ or otherwise specified \\
\hline & GLC treated $n=15$ & catheter obstruction & $n=9(60 \%)$ & $0.33( \pm 0.23)$, range $0.026-0.8(n=9)$ \\
\hline & side effects mentioned $n=15(100 \%)$ & erythema necrolyticum migrans & $\mathrm{n}=4(27 \%)$ & $0.3( \pm 0.12)$, range $0.22-0.46(n=4)$ \\
\hline & & insulin autoantibodies & $n=2(13 \%)$ & $0.2(n=1), 1.4 \mathrm{mg} \cdot d(n=1)$ \\
\hline & & subcutaneous infiltrates & $\mathrm{n}=1(7 \%)$ & $5 \mathrm{mg} \cdot d(n=1)$ \\
\hline & & no side effects (specifically mentioned) & $\mathrm{n}=1(7 \%)$ & $0.21(n=1)$ \\
\hline
\end{tabular}


alone $(73 \%)$ or in combination with other drugs or frequent feeds/specific diets $(27 \%)$. For evaluation of side effects we included reports on short-term use of diazoxide, thus evaluating a total number of 644 cases of diazoxide application.

\section{Hypertrichosis}

The most frequent side effect was a mild to severe hypertrichosis, which is thought to appear dose dependent in every patient. Of note, minoxidil, another potassium channel opener has been used as hair-regrowing treatment for more than 20 years [15]. In the evaluated patients hypertrichosis was reported in only $52 \%$ of children and seemed to be dose-independent, e.g. it occurred in a patient treated with a dose as low as $6 \mathrm{mg} / \mathrm{kg} \cdot \mathrm{d}$ [16] but it was not present in several children treated with a dose of $15 \mathrm{mg} / \mathrm{kg}$. d [17]. However, this may be due to underreporting, as hypertrichosis is often considered to be of minor clinical importance. In contrast, for treated patients hypertrichosis might imply stigmatization, leading to psychological distress and ultimately withdrawal of diazoxide, which was reported for two patients $[12,18]$.

Theoretically, topical $\mathrm{K}_{\mathrm{ATP}}$-channel blocker, such as tolbutamide may be able to reduce hair growth, but is has not yet been evaluated systematically for this indication [19].

\section{Fluid retention}

Less frequently, fluid retention and electrolyte imbalances were described without further specification (30 \%). Diazoxide is a benzothiadiazine derivate and decreases renal sodium-, chloride- as well as bicarbonate excretion without affecting potassium excretion leading to an expansion of extracellular fluid volume [20-22]. This appears to be opposite to other benozothiadiazines, which can antagonize water and sodium retention during diazoxide treatment [21]. Therefore, diazoxide is often combined with hydrochlorothiazide (HCT). Given the low rate of fluid imbalances with diazoxide, a combined treatment is not always necessary. However, under certain conditions it seems reasonable to start with a low dose of diazoxide and to gradually increase the dose over the first few days of treatment, e.g. in newborns with a high glucose infusion rate (fluid overload) and/or cardiac risk factors. Alternatively, if one whishes to start with a higher dose of diazoxide, a combined treatment with diazoxide and HCT can be considered even though signs of fluid retention are not yet present. The latter approach allows a more rapid transition to alternative treatment in case of diazoxide unresponsiveness.

\section{Gastrointestinal symptoms (GI-symptoms)}

Gastrointestinal (GI) symptoms, such as poor appetite, nausea and vomiting occurred in $12 \%$ of patients.
Though not generally being severe, these can complicate treatment in CHI especially if additional dietary treatment is needed.

Severe side effects of diazoxide, i.e. heart failure $(3.7 \%)$, renal failure and petechiae $(0.6 \%)$ or anaphylactic reactions $(0.9 \%)$ and laboratory parameters of bone marrow suppression (4\%) were rarely seen. In many of these cases, a causal relation between diazoxide and these side effects might be disputable.

\section{Cardiotoxicity}

Cardiotoxicity of diazoxide has been questioned by various authors. Cardiomyopathy in CHI resembles cardiomyopathy seen in children of diabetic mothers, suggesting hyperinsulinemia and not diazoxide treatment as the underlying cause [23, 24]. However, the temporal relation between cessation of diazoxide treatment and resolution of cardiac abnormalities despite persistent hyperinsulinemia as described for some patients suggests a causative role of diazoxide [25]. Cardiac failure might be indirectly caused by diazoxide through water and salt retention and thus fluid overload [26] or directly by inducing an increase in pulmonary blood flow resulting in an increased right ventricular work as shown in patients with primary pulmonary hypertension [27].

Finally, in cardiomycoytes Kir6.2 is integral in the make-up of myocellular $\mathrm{K}_{\mathrm{ATP}}$-channels and $\mathrm{K}_{\mathrm{ATP}}$-channel malfunction has been implicated in the development and progression of heart disease $[24,28]$. Taken together, heart failure could ultimately result from 1) hyperinsulinemia itself, 2) diazoxide treatment, most probably as a secondary complication due to fluid overload or due to a direct hemodynamic effect on pulmonary blood flow or 3) an underlying $K_{\mathrm{ATP}}$-channel mutation.

\section{Renal failure}

Two patients developed renal failure under treatment with diazoxide $(<1 \%)$. Both suffered from oliguria with elevated urea- or creatinin-levels and additionally developed petechiae, either generalized or as quick transient petechial rash on the back of the feet while coagulation profile and/or platelet count was normal [29, 30]. These both patients had additional problems, i.e. fluid retention and cardiac decompensation or infection. Therefore it seems more likely that renal failure was indirectly caused rather than being due to nephrotoxicity of diazoxide.

\section{Anaphylactic reaction and bone marrow suppression}

Anaphylactic reactions were described for three patients $(<1 \%)$, requiring reduction of diazoxide dose from $600 \mathrm{mg} \cdot \mathrm{d}$ to $350 \mathrm{mg} \cdot \mathrm{d}$ in an adult patient with adultonset nesidioblastosis with facial flushing, edema and a slight decrease in blood pressure from $140 / 78 \mathrm{mmHg}$ to $120 / 70 \mathrm{mmHg}$ [31] or cessation of diazoxide treatment 
in two patients with recurrent rash or severe anaphylactic reaction (not further specified), respectively [32]. Bone marrow suppression (leucopenia, isolated neutropenia or thrombocytopenia) occurred in 11 patients (3\%) with $\mathrm{CHI}$ and in two further patients of which one additionally suffered from pulmonary hypertension and heart failure, whereas in the other hyperinsulinism was due to Münchausen syndrome by proxy [33, 34]. In these two patients neutropenia resolved when diazoxide was ceased. In another two patients diazoxide treatment was ceased due to neutropenia [12, 35], in the others outcome was not mentioned. Severe infection was not mentioned for any patient with leucopenia suggesting that this was not the case.

In summary, diazoxide is still the first line drug in the treatment of hyperinsulinism. It is easy to apply and generally well tolerated. Common side effects are usually not severe. A causal relation between diazoxide and severe side effects remains doubtful as there are only very few cases reported and detailed information on the course of treatment is limited.

\section{Octreotide}

The hypothalamic release-inhibiting hormone somatostatin is a cyclic polypeptide that is found throughout the nervous and gastrointestinal system. It binds to specific membrane receptors called somatostatin receptors (SSTR1-SSTR5) [36]. In the pancreas, somatostatin has inhibitory effects on the release of glucagon and insulin from the pancreatic islet cells and suppresses the incretin glucagon-like-peptide 1 (GLP-1) [37]. Other actions include inhibition of gastrointestinal motility, gallbladder contractility and splanchnic blood flow [38]. Early somatostatin infusion tests in infants and children with hyperinsulinism confirmed its efficacy in $\mathrm{CHI}[39,40]$. However, clinical use of somatostatin was restricted due to its half-life of less than three minutes [36]. Therefore, various synthetic analogues of somatostatin were tested for its efficacy in CHI [41-43]. Octreotide and lanreotide have a prolonged half-life of 90 minutes (octreotide) and 23-30 days (lanreotide), respectively, when administered by subcutaneous (s.c.) or intramuscular (i.m., lanreotide) injections (FDA). Though not officially approved for this indication it is now common to use somatostatin analogues in the treatment of hyperinsulinism (off-label use). The use of lanreotide as an alternative to octreotide pump treatment is relatively new but has already been proven successful in children with CHI $[42,43]$. Recently, a new somatostatin analogue preferably binding to SSTR5 (pasireotide), was granted marketing for treatment of cushing's disease [44]. In future, pasireotide could also be of use in the treatment of $\mathrm{CHI}$.

In total, 100 patients were treated long-term with octreotide (79 \%) or lanreotide (21\%), either alone $(54 \%)$ or in combination with other drugs or frequent feeds/specific diets (46\%). For evaluation of side effects we again included reports on short-term use of somatostatin analogues (in total 355 cases).

\section{Tachyphylaxis}

An important aspect of somatostatin analogues in the treatment of $\mathrm{CHI}$ is the loss of effect during prolonged treatment (tachyphylaxis), which usually occurs within the first days or weeks of treatment. Tachyphylaxis occurred in a total number of 20 patients with CHI (18\%). Interestingly, tachyphylaxis is generally not observed in patients treated with octreotide for acromegaly. Several authors propose tachyphylaxis to be caused by gastrointestinal adaption, e.g. through tissue-specific desensitization or down-regulation of somatostatin receptors while SSTR expressed in pituitary tumours might have a different turn-over rate and thus escape local adaption [36-38].

\section{Gastrointestinal symptoms, gallstones, hepatitis}

Most adverse effects such as abdominal pain or stool abnormalities were mild and resolved spontaneously within a few weeks under ongoing treatment. Further gastrointestinal side effects include gallstones and necrotizing enterocolitis (NEC), which can be partially explained by the action profile of natural somatostatins. Of the evaluated patients only four of them were reported to have gallstones $(3.6 \%)[42,43,45,46]$, of which three were asymptomatic and octreotide/lanreotide treatment was continued in combination with ursodeoxycholic acid. However, the incidence of asymptomatic gallstones might be higher. In acromegaly, up to $20-30 \%$ of patients treated with octreotide develop gallstones [36] consistent with a recent report of 28 patients with $\mathrm{CHI}$ on octreotide treatment in which gallbladder pathology was detected in $32 \%$ of children [10]. Since the recognition or prevention of asymptomatic gallstones might help to prevent complications, routine ultrasound once a year or prophylactic treatment with ursodeoxycholic acid during treatment with somatostatin analogues seems feasible. In three patients liver enzymes increased while on treatment with octreotide, which returned to normal levels in all when treatment was ceased [47-49]. Interestingly, in two of these, octreotide-induced hepatitis was associated with either a high dose (up to $40 \mu \mathrm{g} / \mathrm{kg} \cdot \mathrm{d}$ ) or with a gradual increase in dose from 5 to $10 \mu \mathrm{g} / \mathrm{kg} \cdot \mathrm{d}$. This finding stresses the importance of dose in the development of octreotide-induced hepatitis and warrants routine examination of liver function tests particularly when high doses are given or when dosing is increased [47].

\section{Necrotizing enterocolitis (NEC)}

The most severe side effect that is discussed to be associated with somatostatin analogues is NEC. A causal relation between octreotide and NEC is not yet proven, 
although the substantial reduction in splanchnic blood flow induced by octreotide suggests a causative role [50].

Four of eight children that developed NEC while on treatment with octreotide clearly had other risk factors for NEC: severe cardiomyopathy $(n=1)$ [51], congestive heart failure due to excessive fluid overload $(n=2)[52,53]$, and a patent ductus arteriosus (PDA) $(n=1)$ [50]. Remarkably, in one of these patients the condition quickly improved upon adequate treatment even though octreotide was increased twofold [50]. Severity of NEC ranged from bloody stools to death $(n=2)$. Another patient additionally received nifedipine and metoclopramide, which could as well have contributed to the development of bowel gangrene [50]. Of the remaining three patients, two had no additional extrinsic risk factors and for one patient detailed clinical history was not provided [50]. Six of the patients that developed NEC were full-term neonates, for two patients gestational age was not given. All children received octreotide within the first month of life, for one child age was not given. The occurrence of NEC may be associated with the applied dose, as a dose-dependent reduction in splanchnic blood flow was shown in rats [54]. All children that developed NEC received a dose $\geq 15 \mu \mathrm{g} / \mathrm{kg} \cdot \mathrm{d}$ and the mean dose of $21.5( \pm 4.7) \mu \mathrm{g} / \mathrm{kg} \cdot \mathrm{d}$ was remarkably higher than the mean dose in patients without NEC $(14.9 \mu \mathrm{g} / \mathrm{kg} \cdot \mathrm{d})$.

An additional three neonates with NEC were treated with octreotide for other indications. One of these patients was born premature and had a PDA [55], the other two both have had extensive cardiac surgery previous to the development of NEC with documented distal aortic ischemia in one patient $[50,56]$. An adult patient treated with octreotide for another indication already had pre-existing gastrointestinal symptoms with abdominal distension and steatorrhoea, which worsened under treatment with octreotide.

Taken together, in most of the cases reported octreotide is merely a risk factor among others. However, all children received octreotide within the first months of life, all of them developed NEC within the first days or weeks of treatment and all except one were treated with a dose $\geq 15 \mu \mathrm{g} / \mathrm{kg} \cdot \mathrm{d}$.

\section{Growth deceleration}

Since somatostatin inhibits growth hormone secretion, treatment with somatostatin analogues might compromise growth velocity. Mild growth deceleration was observed in 15 patients (13.5\%) [42, 45, 57-60]. Of these, eight patients caught up after treatment was discontinued, dose decreased or even under ongoing treatment. In these patients, height normalized appropriate for parental target height. Only five patients
(4.5\%) continued to grow below their target range $[45,57,59,60]$. In one patient outcome was not specified, another patient was still on treatment but height remained only 0.6 SD below the expected height. For 52 patients $(47 \%)$ it was particularly mentioned that they grew normal while on long-term treatment with somatostatin analogues. In summary, the risk of persistent growth deceleration and inappropriate target height is very low. Nevertheless, growth should be closely monitored in all patients during and after somatostatin analogue treatment.

\section{Calcium channel antagonists}

Calcium channel antagonists such as nifedipine or amlodipine are approved for treatment of hypertension and angina pectoris. Their use in treatment of $\mathrm{CHI}$ is relatively new. They inhibit the transmembrane influx of calcium ions into the pancreatic beta cells, known to be an essential trigger for insulin secretion [11]. However, most hyperinsulinism centers do not consider these drugs as indicated because of the lack of effectiveness. Therefore, in the treatment of $\mathrm{CHI}$, calcium channel antagonists are merely used as a third-line drug, e.g. as an add-on treatment, in partial diazoxide/octreotide resistance, and/or following partial pancreatectomy [16, 61, 62]. In fact, $40 \%$ of the evaluated patients had partial to sub-total pancreatectomy previous to treatment with calcium channel antagonist, compared to $3 \%$ and $17 \%$ of patients treated with diazoxide and somatostatin analogues, respectively. Possible side effects include hypotension, peripheral edema, headache, flushing, dizziness and nausea (FDA). In CHI, calcium channel antagonists were well tolerated, which might be related to the relatively low dose: mean dose was 0.72 $( \pm 0.36) \mathrm{mg} / \mathrm{kg} \cdot \mathrm{d}$ (range $0.1-2 \mathrm{mg} / \mathrm{kg} \cdot \mathrm{d}$ ) in patients treated with nifedipine and $0.1 \mathrm{mg} / \mathrm{kg} \cdot \mathrm{d}$ in two patients treated with amlodipine, respectively, which is in the lower range of the recommended dose for the treatment of hypertension in pediatric patients (nifedipine: 0.25-3 $\mathrm{mg} / \mathrm{kg} \cdot \mathrm{d}$; amlodipine: $0.05-0.5 \mathrm{mg} / \mathrm{kg} \cdot \mathrm{d}$ ) [63].

In summary, while calcium channel antagonists are safe in the treatment of hyperinsulinism, these agents do not seem to sufficiently restore normoglycemia and are therefore in our opinion not indicated as first line drugs in the treatment of $\mathrm{CHI}$.

\section{Glucagon}

Glucagon is a polypeptide hormone physiologically secreted by alpha cells of the pancreatic islets to promote hepatic glycogenolysis and gluconeogenesis and thus directly increases blood glucose levels [6]. Initially, intravenous glucagon infusion is often used in $\mathrm{CHI}$ for several days or weeks to stabilize blood glucose levels, however, its long-term use is limited due 
to its short half-life and the need for parenteral administration.

Only 7 patients were treated long-term with glucagon, either continuously s.c. or by frequent injections s.c. or i.m [64-68]. Importantly, in all but one patient glucagon was used in combination with other drugs or following subtotal pancreatectomy. Continuous s.c. glucagon infusion is frequently complicated by catheter obstructions occurring daily or 2-3 times per week [65]. A stabilized formulation of glucagon was successfully administered in three children until surgery could be performed resulting in less problems regarding catheter blockage [65]. Two of these patients and two additional patients reported by Wald et al. developed erythema necrolyticum migrans [65, 69]. This might be explained by an increased bioavailability of the stabilized formulation of glucagon and by the relatively high dose (up to $0.22 \mathrm{mg} / \mathrm{kg} \cdot \mathrm{d}$ intravenous (i.v.) and $0.26 \mathrm{mg} / \mathrm{kg} \cdot \mathrm{d}$ s.c.) administered in the two patients reported by Wald et al., respectively. In these four patients glucagon was administered s.c. over periods of up to 3.5 months $(n=3)$ or i.v. as short-term management of hypoglycemia $(n=1)$. In all patients lesions resolved without scarring. Less severe side effects included subcutaneous infiltrates at the site of injection $(n=1)$ [67] and the development of insulin autoantibodies $(n=2)$, possibly due to the amount of insulin in the glucagon preparation (up to $0.02 \%$ ) $[64,68]$.

In summary, glucagon is very helpful for the treatment of hypoglycemia within the first weeks of life and it might be beneficial following pancreatectomy and as an add-on treatment, particularly in combination with a somatostatin analogue to replace the octreotide/lanreotide-induced suppression of endogenous glucagon secretion. However, long-term treatment is still limited by the lack of a suitable preparation for continuous s.c. infusion.

\section{Outlook}

Although there is a broad spectrum of drugs available for children with $\mathrm{CHI}$, a considerable number of patients do not show sufficient response to existing medical treatment. Therefore, efforts are made to provide these patients with alternative drugs. Recently, exendin-(9-39) a specific GLP-1 receptor antagonist was shown to elevate fasting blood glucose levels in nine individuals with $\mathrm{K}_{\mathrm{ATP}}$-CHI [70]. Furthermore, the mammalian target of rapamycin (mTor) inhibitor sirolimus has recently been proven successful in four infants with severe hyperinsulinemic hypoglycemia unresponsive to diazoxide [71]. Another promising approach is the development of new somatostatin analogues, such as pasireotide, with modified binding profiles and thus possibly a stronger inhibitory effect on insulin secretion [44].

\section{Conclusion}

Despite increasing knowledge on etiology, data available on long-term conservative treatment of $\mathrm{CHI}$ are still poor. There exists an urgent need for prospective studies or registers to better evaluate safety and efficacy of drug treatment in CHI. This work serves as a basis to reconsider treatment strategies and provides information especially on a rough frequency and impact of rare side effects of drugs given to patients with $\mathrm{CHI}$.

Recommendations based on our analysis:

Diazoxide

- it is important to screen for signs of fluid retention; to monitor blood gases, sodium, chloride,

bicarbonate and potassium level, in particular within the first weeks of treatment and when glucose infusion rate is high; when indicated hydrochlorothiazide should be added.

- in neonates cardiac monitoring (echocardiography) should be performed.

Somatostatin analogues

- somatostatin analogues should be avoided in neonates, particularly if additional risk factors for NEC are present; if not possible, an initial dose should not be higher than $15 \mu \mathrm{g} / \mathrm{kg} \quad \mathrm{d}$ and excessive fluid overload must be prevented, as this may trigger the risk of NEC; treatment must immediately be stopped once any sign of NEC is present.

- routine abdominal ultrasound should be performed prior to and every 12 months after initiation of treatment; if gallstones are present ursodeoxycholic acid should be added.

- growth curves must be monitored; dose should only be decreased if marked growth deceleration becomes evident, as in most of the children the decrease in growth velocity is transient.

- liver function must be monitored, particularly if using a high dose or when dosing is increased.

- lanreotide should not be used in neonates as severe side effects might require immediate discontinuation of treatment.

\section{Competing interests}

The authors declare that they have no competing interests.

\section{Authors' contributions}

AW, CL, SK, BS and JM contributed to the acquisition of data. AW analyzed and interpreted the data with input from $C L, S K$, JM and BS. CL, SK, TM and EM contributed to the conception and design of the study and made substantial contributions to the interpretation of data. AW, SK and TM wrote the manuscript with intellectual input from JM, BS and EM. All authors read and approved the final manuscript

\section{Funding}

This research did not receive any specific grant from any funding agency in the public, commercial or not-for-profit sector. 


\section{Author details}

${ }^{1}$ Department of General Pediatrics, Neonatology and Pediatric Cardiology, University Children's Hospital Duesseldorff, Moorenstrasse 5, Duesseldorf D-40225, Germany. ${ }^{2}$ Cochrane Metabolic and Endocrine Disorders Group, Institute of General Practice, Duesseldorf University Hospital, Duesseldorf, Germany. ${ }^{3}$ Department of Pediatric Kidney, Liver and Metabolic Diseases, Hannover Medical School, Hannover Medical School, Germany. ${ }^{4}$ Neonatal Intensive Care Unit, Cambridge University Hospitals NHS Foundation Trust, Cambridge, UK. ${ }^{5}$ University Department of Obstetrics \& Gynaecology, University of Cambridge, Cambridge, UK.

Received: 14 August 2015 Accepted: 15 November 2015 Published online: 25 November 2015

\section{References}

1. Meissner T, Mayatepek E. Clinical and genetic heterogeneity in congenital hyperinsulinism. Eur J Pediatr. 2002;161(1):6-20.

2. Snider KE, Becker S, Boyajian L, Shyng SL, MacMullen C, Hughes N, et al. Genotype and phenotype correlations in 417 children with congenital hyperinsulinism. J Clin Endocrinol Metab. 2013;98(2):E355-63. doi:10.1210/jc.2012-2169.

3. Kapoor RR, Flanagan SE, Arya VB, Shield JP, Ellard S, Hussain K. Clinical and molecular characterisation of 300 patients with congenital hyperinsulinism. European journal of endocrinology / European Federation of Endocrine Societies. 2013;168(4):557-64. doi:10.1530/EJE-12-0673.

4. Laje P, States $\amalg$, Zhuang H, Becker SA, Palladino AA, Stanley CA, et al. Accuracy of PET/CT Scan in the diagnosis of the focal form of congenital hyperinsulinism. J Pediatr Surg. 2013;48(2):388-93. doi:10.1016/j.jpedsurg. 2012.11.025.

5. Cretolle C, Fekete CN, Jan D, Nassogne MC, Saudubray JM, Brunelle F, et al. Partial elective pancreatectomy is curative in focal form of permanent hyperinsulinemic hypoglycaemia in infancy: A report of 45 cases from 1983 to 2000. J Pediatr Surg. 2002;37(2):155-8.

6. Arnoux JB, Verkarre V, Saint-Martin C, Montravers F, Brassier A, Valayannopoulos $\checkmark$, et al. Congenital hyperinsulinism: current trends in diagnosis and therapy. Orphanet J Rare Dis. 2011;6:63. doi:10.1186/1750-1172-6-63.

7. Lord K, Dzata E, Snider KE, Gallagher PR, De Leon DD. Clinical presentation and management of children with diffuse and focal hyperinsulinism: a review of 223 cases. J Clin Endocrinol Metab. 2013;98(11):E1786-9. doi:10.1210/jc.2013-2094.

8. Levy-Shraga Y, Pinhas-Hamiel O, Kraus-Houminer E, Landau H, MazorAronovitch K, Modan-Moses D, et al. Cognitive and developmental outcome of conservatively treated children with congenital hyperinsulinism. Journal of pediatric endocrinology \& metabolism : JPEM. 2013;26(3-4):301-8. doi:10.1515/jpem-2012-0289.

9. Yorifuji T. Congenital hyperinsulinism: current status and future perspectives. Annals of pediatric endocrinology \& metabolism. 2014; 19(2):57-68. doi:10.6065/apem.2014.19.2.57.

10. Demirbilek H, Shah P, Arya VB, Hinchey L, Flanagan SE, Ellard S, et al. Longterm follow-up of children with congenital hyperinsulinism on octreotide therapy. J Clin Endocrinol Metab. 2014;99(10):3660-7. doi:10.1210/jc.2014-1866.

11. Muller D, Zimmering M, Roehr CC. Should nifedipine be used to counter low blood sugar levels in children with persistent hyperinsulinaemic hypoglycaemia? Arch Dis Child. 2004;89(1):83-5.

12. Touati G, Poggi-Travert F, Ogier De Baulny H, Rahier J, Brunelle F, NihoulFekete $C$, et al. Long-term treatment of persistent hyperinsulinaemic hypoglycaemia of infancy with diazoxide: a retrospective review of 77 cases and analysis of efficacy-predicting criteria. Eur J Pediatr. 1998;157(8):628-33.

13. Magge SN, Shyng SL, MacMullen C, Steinkrauss L, Ganguly A, Katz LE, et al. Familial leucine-sensitive hypoglycemia of infancy due to a dominant mutation of the beta-cell sulfonylurea receptor. J Clin Endocrinol Metab. 2004;89(9):4450-6. doi:10.1210/jc.2004-0441.

14. de Lonlay P, Fournet JC, Touati G, Groos MS, Martin D, Sevin C, et al. Heterogeneity of persistent hyperinsulinaemic hypoglycaemia. A series of 175 cases. Eur J Pediatr. 2002;161(1):37-48.

15. Alsantali A, Shapiro J. Androgens and hair loss. Curr Opin Endocrinol Diabetes Obes. 2009;16(3):246-53.

16. Eichmann D, Hufnagel M, Quick $P$, Santer R. Treatment of hyperinsulinaemic hypoglycaemia with nifedipine. Eur J Pediatr. 1999;158(3):204-6.

17. Guerrero-Fernandez J, Gonzalez Casado I, Espinoza Colindres L, Gracia Bouthelier R. Congenital hyperinsulinism. Review of 22 cases. An Pediatr (Barc). 2006;65(1):22-31.
18. Darendeliler F, Fournet JC, Bas F, Junien C, Gross MS, Bundak R, et al. ABCC8 (SUR1) and KCNJ11 (KIR6.2) mutations in persistent hyperinsulinemic hypoglycemia of infancy and evaluation of different therapeutic measures. Journal of pediatric endocrinology \& metabolism : JPEM. 2002;15(7):993-1000

19. Shorter K, Farjo NP, Picksley SM, Randall VA. Human hair follicles contain two forms of ATP-sensitive potassium channels, only one of which is sensitive to minoxidil. FASEB journal : official publication of the Federation of American Societies for Experimental Biology. 2008;22(6):1725-36. doi:10.1096/fj.07-099424.

20. Green TP. Systemic vasodilatation and renal sodium excretion: effects of hydralazine and diazoxide. Life Sci. 1984;34(22):2169-76.

21. Bartorelli C, Gargano N, Leonetti G, Zanchetti A. Hypotensive and renal effects of diazoxide, a sodiumretaining benzothiadiazine compound. Circulation. 1963;27:895-903.

22. Hutcheon DE, Barthalmus KS. Antihypertensive action of diazoxide. A new benzothiazine with antidiuretic properties. Br Med J. 1962;2(5298):159-61.

23. Parker JJ, Allen DB. Hypertrophic cardiomyopathy after prolonged diazoxide therapy for hyperinsulinemic hypoglycemia. J Pediatr. 1991;118(6):906-9.

24. Huang T, Kelly A, Becker SA, Cohen MS, Stanley CA. Hypertrophic cardiomyopathy in neonates with congenital hyperinsulinism. Arch Dis Child Fetal Neonatal Ed. 2013;98(4):F351-4. doi:10.1136/archdischild-2012-302546.

25. McGraw ME, Price DA. Complications of diazoxide in the treatment of nesidioblastosis. Arch Dis Child. 1985;60(1):62-4.

26. Gillies DR. Complications of diazoxide in the treatment of nesidioblastosis. Arch Dis Child. 1985;60(5):500-1.

27. Honey $\mathrm{M}$, Cotter L, Davies N, Denison D. Clinical and haemodynamic effects of diazoxide in primary pulmonary hypertension. Thorax. 1980;35(4):269-76.

28. Olson TM, Terzic A. Human K(ATP) channelopathies: diseases of metabolic homeostasis. Pflugers Arch - Eur J Physiol. 2010;460(2):295-306. doi:10.1007/s00424-009-0771-y.

29. Low LC, Yu EC, Chow OK, Yeung CY, Young RT. Hyperinsulinism in infancy. Aust Paediatr J. 1989;25(3):174-7.

30. Kaleva NN, Ivanov IS, Panova MV, Shabanova TD, Delgyanska DS Hyperinsulinemic hypoglycemias in infancy and childhood-diagnostic therapeutic algorithm with contribution of two cases. Folia Med. 2010;52(3): 62-9.

31. Arao T, Okada Y, Hirose A, Tanaka Y. A rare case of adult-onset nesidioblastosis treated successfully with diazoxide. Endocr J. 2006;53(1):95-100.

32. Meissner T, Wendel U, Burgard P, Schaetzle S, Mayatepek E. Long-term follow-up of 114 patients with congenital hyperinsulinism. European journal of endocrinology / European Federation of Endocrine Societies. 2003;149(1):43-51.

33. Ozon A, Demirbilek H, Ertugrul A, Unal S, Gumruk F, Kandemir N. Anemia and neutropenic fever with high dose diazoxide treatment in a case with hyperinsulinism due to Munchausen by proxy. Journal of pediatric endocrinology \& metabolism : JPEM. 2010;23(7):719-23.

34. Yildizdas D, Erdem S, Kucukosmanoglu O, Yilmaz M, Yuksel B. Pulmonary hypertension, heart failure and neutropenia due to diazoxide therapy. Adv Ther. 2008;25(5):515-9. doi:10.1007/s12325-008-0049-3.

35. Dupont C, Chaussain JL, Boudaillez B, Chenut B. High-titer glucagon antibodies in a hypoglycemic child on glucagon therapy. J Pediatr Gastroenterol Nutr. 1982;1(3):449-51.

36. Lamberts SW, van der Lely AJ, de Herder WW, Hofland L. Octreotide. N Engl J Med. 1996;334(4):246-54. doi:10.1056/NEJM199601253340408.

37. Plockinger U, Holst JJ, Messerschmidt D, Hopfenmuller W, Quabbe HJ. Octreotide suppresses the incretin glucagon-like peptide (7-36) amide in patients with acromegaly or clinically nonfunctioning pituitary tumors and in healthy subjects. European journal of endocrinology/European Federation of Endocrine Societies. 1999:140(6):538-44.

38. Grosman I, Simon D. Potential gastrointestinal uses of somatostain and its synthetic analogue octreotide. Am J Gastroenterol. 1990;85(9):1061-72.

39. Hirsch HJ, Loo S, Evans N, Crigler JF, Filler RM, Gabbay KH. Hypoglycemia of infancy and nesidioblastosis. Studies with somatostatin. N Engl J Med. 1977; 296(23):1323-6. doi:10.1056/NEJM197706092962305.

40. Aynsley-Green A, Barnes ND, Adrian TE, Kingston J, Boyes S, Bloom SR. Effect of somatostatin infusion on intermediary metabolism and entero-insular hormone release in infants with hyperinsulinaemic hypoglycaemia. Acta Paediatr Scand. 1981;70(6):889-95.

41. Glaser B, Landau H, Smilovici A, Nesher R. Persistent hyperinsulinaemic hypoglycaemia of infancy: long-term treatment with the somatostatin analogue Sandostatin. Clin Endocrinol (Oxf). 1989;31(1):71-80.

42. Modan-Moses D, Koren I, Mazor-Aronovitch K, Pinhas-Hamiel O, Landau H. Treatment of congenital hyperinsulinism with lanreotide acetate 
(Somatuline Autogel). J Clin Endocrinol Metab. 2011;96(8):2312-7. doi:10. 1210/jc.2011-0605.

43. Kuhnen P, Marquard J, Ernert A, Meissner T, Raile K, Wannenmacher G, et al. Long-term lanreotide treatment in six patients with congenital hyperinsulinism. Horm Res Paediatr. 2012;78(2):106-12. doi:10.1159/000341525.

44. Feelders RA, Yasothan U, Kirkpatrick P. Pasireotide. Nat Rev Drug Discov. 2012;11(8):597-8. doi:10.1038/nrd3788.

45. Glaser B, Hirsch HJ, Landau H. Persistent hyperinsulinemic hypoglycemia of infancy: long-term octreotide treatment without pancreatectomy. J Pediatr. 1993;123(4):644-50.

46. Radetti G, Gentili L, Paganini C, Messner H. Cholelithiasis in a newborn following treatment with the somatostatin analogue octreotide. Eur J Pediatr. 2000;159(7):550.

47. Ben-Ari J, Greenberg M, Nemet D, Edelstein E, Eliakim A. Octreotide-induced hepatitis in a child with persistent hyperinsulinemia hypoglycemia of infancy. Journal of pediatric endocrinology \& metabolism : JPEM. 2013;26 (1-2):179-82. doi:10.1515/jpem-2012-0349.

48. Koren I, Riskin A, Barthlen W, Gillis D. Hepatitis in an infant treated with octreotide for congenital hyperinsulinism. Journal of pediatric endocrinology \& metabolism : JPEM. 2013;26(1-2):183-5. doi:10.1515/jpem-2012-0372.

49. Avatapalle B, Padidela R, Randell T, Banerjee I. Drug-induced hepatitis following use of octreotide for long-term treatment of congenital hyperinsulinism. BMJ case reports. 2012;2012. doi:10.1136/bcr-2012006271

50. Laje P, Halaby L, Adzick NS, Stanley CA. Necrotizing enterocolitis in neonates receiving octreotide for the management of congenital hyperinsulinism. Pediatr Diabetes. 2010;11 (2):142-7. doi:10.1111/.j1399-5448.2009.00547x.x.

51. Al-Nassar S, Sakati N, Al-Ashwal A, Bin-Abbas B. Persistent hyperinsulinaemic hypoglycaemia of infancy in 43 children: long-term clinical and surgical follow-up. Asian journal of surgery / Asian Surgical Association. 2006;29(3): 207-11. doi:10.1016/S1015-9584(09)60089-0.

52. Kulkarni MS, Upadhyay VA. Nesidioblastosis with necrotising enterocolitis: an enigma. Pediatr Surg Int. 2000;16(5-6):426-8.

53. Austin JD, Hofman P, Anderson BJ. Life-threatening hyperkalemia following partial pancreatectomy for neonatal hyperinsulinism. Pediatric critical care medicine : a journal of the Society of Critical Care Medicine and the World Federation of Pediatric Intensive and Critical Care Societies. 2008;9(3):e17-9. doi:10.1097/PCC.0b013e3181728c82.

54. Carlsson PO, Jansson L. The long-acting somatostatin analogue octreotide decreases pancreatic islet blood flow in rats. Pancreas. 1994;9(3):361-4.

55. Rasiah SV, Oei J, Lui K. Octreotide in the treatment of congenital chylothorax. J Paediatr Child Health. 2004;40(9-10):585-8. doi:10.1111/j.1440-1754.2004.00471.x.

56. Mohseni-Bod H, Macrae D, Slavik Z. Somatostatin analog (octreotide) in management of neonatal postoperative chylothorax: is it safe? Pediatric critical care medicine : a journal of the Society of Critical Care Medicine and the World Federation of Pediatric Intensive and Critical Care Societies. 2004; 5(4):356-7.

57. Mazor-Aronovitch K, Gillis D, Lobel D, Hirsch HJ, Pinhas-Hamiel O, ModanMoses $\mathrm{D}$, et al. Long-term neurodevelopmental outcome in conservatively treated congenital hyperinsulinism. European journal of endocrinology/ European Federation of Endocrine Societies. 2007;157(4):491-7. doi:10.1530/EJE-07-0445.

58. Yorifuji T, Kawakita R, Hosokawa Y, Fujimaru R, Matsubara K, Aizu K, et al. Efficacy and safety of long-term, continuous subcutaneous octreotide infusion for patients with different subtypes of KATP-channel hyperinsulinism. Clin Endocrinol (Oxf). 2013;78(6):891-7. doi:10.1111/cen.12075.

59. Jackson JA, Hahn Jr HB, Oltorf CE. Long-acting somatostatin analog in refractory neonatal hypoglycemia: follow-up information. J Pediatr. 1988; 113(6): 1118

60. Thornton PS, Alter CA, Katz LE, Baker L, Stanley CA. Short- and long-term use of octreotide in the treatment of congenital hyperinsulinism. J Pediatr. 1993;123(4):637-43.

61. Lindley KJ, Dunne MJ, Kane C, Shepherd RM, Squires PE, James RF, et al. Ionic control of beta cell function in nesidioblastosis. A possible therapeutic role for calcium channel blockade. Arch Dis Child. 1996;74(5):373-8.

62. Suprasongsin C, Suthutvoravut U, Mahachoklertwattana P, Preeyasombat C. Combined raw cornstarch and nifedipine as an additional treatment in persistent hyperinsulinemic hypoglycemia of infancy. Journal of the Medical Association of Thailand $=$ Chotmaihet thangphaet. 1999;82 Suppl 1:S39-42.

63. Norwood VF. Hypertension. Pediatrics in review/American Academy of Pediatrics. 2002;23(6):197-208.
64. Rose SR, Chrousos G, Cornblath M, Sidbury J. Management of postoperative nesidioblastosis with zinc protamine glucagon and oral starch. J Pediatr. 1986;108(1):97-100.

65. Mohnike K, Blankenstein O, Pfuetzner A, Potzsch S, Schober E, Steiner S, et al. Long-term non-surgical therapy of severe persistent congenital hyperinsulinism with glucagon. Horm Res. 2008;70(1):59-64. doi:10.1159/000129680.

66. Neylon OM, Moran MM, Pellicano A, Nightingale M, O'Connell MA. Successful subcutaneous glucagon use for persistent hypoglycaemia in congenital hyperinsulinism. Journal of pediatric endocrinology \& metabolism : JPEM. 2013;26(11-12):1157-61. doi:10.1515/jpem-2013-0115.

67. Storm K, Christensen PE. Nesidioblastosis. Long-term treatment of hypoglycemia with zinc-protamine glucagon. Ugeskr Laeger. 1982;144(31):2296-7.

68. Sovik O, Fevang FO, Finne PH. Insulin antibodies in an infant with hyperinsulinism and persistent hypoglycaemia treated with glucagon. Diabetologia. 1981;21(2):160.

69. Wald M, Lawrenz K, Luckner D, Seimann R, Mohnike K, Schober E. Glucagon therapy as a possible cause of erythema necrolyticum migrans in two neonates with persistent hyperinsulinaemic hypoglycaemia. Eur J Pediatr. 2002;161(11):600-3. doi:10.1007/s00431-002-1022-9.

70. Calabria AC, Li C, Gallagher PR, Stanley CA, De Leon DD. GLP-1 receptor antagonist exendin-(9-39) elevates fasting blood glucose levels in congenital hyperinsulinism owing to inactivating mutations in the ATPsensitive K+ channel. Diabetes. 2012;61(10):2585-91. doi:10.2337/db12-0166.

71. Senniappan S, Alexandrescu S, Tatevian N, Shah P, Arya V, Flanagan S, et al. Sirolimus therapy in infants with severe hyperinsulinemic hypoglycemia. N Engl J Med. 2014;370(12):1131-7. doi:10.1056/NEJMoa1310967.

\section{Submit your next manuscript to BioMed Central and we will help you at every step:}

- We accept pre-submission inquiries

- Our selector tool helps you to find the most relevant journal

- We provide round the clock customer support

- Convenient online submission

- Thorough peer review

- Inclusion in PubMed and all major indexing services

- Maximum visibility for your research

Submit your manuscript at www.biomedcentral.com/submit 